\title{
微量金属元素を添加した高強度黄銅合金の組織構造と力学特性*
}

\author{
渥 美 春 彦*1, 今井久志*2, 李 樹 豊*3 \\ 上坂美治*4, 小島明 倫*4, 近藤勝義*2
}

\section{Microstructure and Mechanical Properties of High Strength Brass Alloy with Some Elements}

\author{
Haruhiko ATSUMI*5, Hisashi IMAI, Shufeng LI, \\ ${ }^{* 5}$ Graduate School of Engineering, Osaka University, \\ 11-1 Mihogaoka, Ibaraki-shi, Osaka, 567-0047 Japan
} Yoshiharu KOUSAKA, Akimichi KOJIMA and Katsuyoshi KONDOH

\begin{abstract}
The purpose of this research is the development of a high strength $\alpha-\beta$ brass $(\mathrm{Cu}-40 \mathrm{Zn})$ with additions of elements of small solid solubility in brass. $\mathrm{Cu}-40 \mathrm{Zn}$ with 0.6 mass\% Tin ( $\mathrm{Sn}$ ) and various contents of Chromium $(\mathrm{Cr})$ and Iron ( $\mathrm{Fe}$ ) were prepared by casting $\left(\mathrm{Cu}^{-}-40 \mathrm{Zn}-\mathrm{CrFeSn}\right)$. The yield strength (YS) and ultimate tensile strength (UTS) of cast $\mathrm{Cu}-40 \mathrm{Zn}-\mathrm{CrFeSn}$ has $190 \mathrm{MPa}$ and $400 \mathrm{MPa}$. Furthermore, the YS and UTS of extruded $\mathrm{Cu}-40 \mathrm{Zn}-\mathrm{CrFeSn}$ was $300 \mathrm{MPa}$ and 600 $\mathrm{MPa}, 23 \%$ and $36 \%$ higher than that of extruded binary $\mathrm{Cu}^{-40} \mathrm{Zn}$ alloy. Vickers micro hardness of $158 \mathrm{Hv}$ was higher than that of extruded $\mathrm{Cu}-40 \mathrm{Zn}$ alloy $(131 \mathrm{Hv})$. In addition, the elongation of extruded $\mathrm{Cu}-40 \mathrm{Zn}-\mathrm{CrFeSn}$ was $35 \%$. The strengthening mechanisms of these alloys were considered as follows; one was a solid solution strengthening of $\mathrm{Cr}$, Fe and $\mathrm{Sn}$ additives which were identified by TEM-EDS and SEM-EDS. The other was increasing of the area ratio of $\beta$-phase in $\mathrm{Cu}^{-} 40 \mathrm{Zn}^{-}$ CrFeSn, compared to that of $\mathrm{Cu}-40 \mathrm{Zn}$.
\end{abstract}

Key Words : Copper Alloy, Brass, Hot Extrusion, Plastic Woking, Hardness, Tensile Properties

\section{1.}

黄銅合金は優れた耐食性，熱・電気伝導性，加工性 を有していることから，配管，ヒートシンクやリード フレームとして利用される. 高力黄銅は 1 3mass\%程度 のアルミニウム，マンガンや鉄などを添加し， $\alpha-\beta$ 相 一の固溶強化，硬質 $\beta$ 相の増加による高強度化がなさ れており，耐腐食性も必要とされる船舶用推進器など に使用される ${ }^{1,2)}$. しかしながら，添加元素量の増加に よる高強度化に伴い，脆性な金属間化合物が多く生成 し, 延性や加工性恃著しく低下する ${ }^{3,4)}$. 本研究では, 鋳造法によりクロム $(\mathrm{Cr})$, 鉄 $(\mathrm{Fe})$, およびスズ $(\mathrm{Sn})$ を微 量添加した $\alpha-\beta$ 二相の高強度黄銅合金を開発した. 添 加元素量を $1 \mathrm{mass} \%$ 以下の微量とすることにより, 金属

* 原稿受付 2010 年 5 月 27 日.

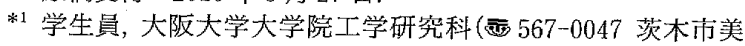
穂が丘 11-1).

*2 正員, 大阪大学接合科学研焭所.

*3 大阪大学接合科学研究所.

*4 正員, サンエツ金属(株) (画 939-1315 砺波市太田 1892).

E-mail : atsumi-h@jwri.osaka-u.ac.jp
間化合物の生成を抑制し，延性や加工性の低下を防ぐ ことが可能である. 既存研究より， $\mathrm{Cr}$ と $\mathrm{Fe}$ は $\mathrm{Cu}$ に対 する固溶限が小さく，Cu にそれぞれ 1mass\%程度添加 した合金は時効硬化型合金に分類される ${ }^{5-7}$. 他方, Sn は $\mathrm{Cu}$ に対する固溶限が大きく，黄銅合金の耐食性と強 度の向上，および湯流れを改善する ${ }^{8}$. これら $\mathrm{Cr}, \mathrm{Fe}$, $\mathrm{Sn}$ 元素を同時に微量添加した黄銅合金の鋳造材および その熱間押出加工材の組織構造と力学特性の調査結果 に基づき, その強化機構を検討した.

\section{2. 陚料と突公方法}

$\mathrm{Cu}-40 \mathrm{mass} \% \mathrm{Zn} の \alpha-\beta$ 二相黄銅合金に 0.6 mass $\% の$ $\mathrm{Sn}$ おうよひ種々の量の $\mathrm{Cr}, \mathrm{Fe}$ を添加した五元系黄銅合 金 $(\mathrm{Cu}-40 \mathrm{mass} \% \mathrm{Zn}-\mathrm{CrFeSn})$ を鋳造法により三種類作製 した(Cast と呼称する). 各試料の元素分析結果を表 1 に示す. 鋳造材より旋船加工にて $\phi 41 \mathrm{~mm}$ のビレット を二つ切り出した. 一方のビレットは, 鋳造材におけ る力学特性を調査するため, 維密化により微細な収縮 单などの鋳造欠陥を除去した. 鋳造材の緻密化には Zn の蒸発を防ぐため, 真空放電プラズマ焼結装置 (SPS-1030S：シンテックス製) を用い， $0.33 \mathrm{~K} / \mathrm{sec} の$ 昇 
Table 1 Chemical compositions of cast ingots (mass\%).

\begin{tabular}{ccccccccccc}
\hline Materials & $\mathrm{Sn}$ & $\mathrm{Pb}$ & $\mathrm{P}$ & $\mathrm{S}$ & $\mathrm{Zn}$ & $\mathrm{Ni}$ & $\mathrm{Fe}$ & $\mathrm{Al}$ & $\mathrm{Cr}$ & $\mathrm{Cu}$ \\
\hline Cast 1 & -0.001 & -0.005 & 0.005 & 0.004 & 38.4 & -0.004 & 0.003 & -0.005 & - & $\mathrm{Bal}$ \\
Cast2 & 0.66 & -0.005 & 0.007 & -0.003 & 40.31 & -0.004 & 0.51 & -0.005 & 0.73 & $\mathrm{Bal}$. \\
Cast3 & 0.64 & -0.005 & 0.005 & 0.004 & 40.44 & -0.004 & 0.33 & -0.005 & 0.49 & $\mathrm{Bal}$. \\
Cast4 & 0.59 & -0.005 & 0.008 & -0.003 & 40.86 & -0.004 & 0.22 & -0.005 & 0.34 & Bal. \\
\hline
\end{tabular}

温速度で $1073 \mathrm{~K}$ まで加熱し，30MPa，1.8ksec 加圧の後 に炉冷した．さらに加熱・加圧を施したビレットをマ ッフル炬(KDF S-70 : デンケン製をを用いて大気雾囲気 にて $923 \mathrm{~K}, 1.8 \mathrm{ksec}$ 保持した後, 冷却速度 $0.06 \mathrm{~K} / \mathrm{sec}$ で 燒鈍した試料を準備した(H.T. cast と呼称する).もう一 方のビレットは, マッフル炬で $\mathrm{Ar}$ 雲囲気にて昇温速度 $0.33 \mathrm{~K} / \mathrm{sec}$ で, $923 \mathrm{~K}$ まで加熱後, $180 \mathrm{sec}$ 保持し, 直ちに 熱間押出加工を施した. 押出加工条件として, 押出速 度 $3 \mathrm{~mm} / \mathrm{sec}$ ，押出比 37 ，コンテナ・ダイス温度 $673 \mathrm{~K}$ を用い， $\phi 7 \mathrm{~mm}$ の丸棒を得た(Ext と呼称する).

また $\alpha, \beta$ 相の面積比率の変化と固溶強化の二つの 高強度化因子の寄与率を定量的に調查するため, 押出 材から長さ $50 \mathrm{~mm}$ の試料を採取し熱処理を施した。 具 体的には，二元系，五元系黄銅合金押出材(Ext1－4)に対 してマッフル饾にて大気雲囲気で $1073 \mathrm{~K}, 1.8 \mathrm{ksec}$ 保持 した後, 一旦, 室温に冷却し押出加工時に導入された ひずみを除去したささらに二元系黄銅合金は $773 \mathrm{~K}$ か ら $1073 \mathrm{~K}$ まで $50 \mathrm{~K}$ 毎に, 熱処理後に続く水焼入れを行 った試料と，水焼入れを施さずひずみの除去だけ行っ た試料の 8 種類を作製した(HT. ext1 と呼称する). 他方， 五元系黄銅合金に関しては，高温で $\beta$ 相単相に変態す ることから, $773 \mathrm{~K} と 1073 \mathrm{~K}$ の水焼入れを行い，同様に 3 種類の試料老作製した(H.T. ext2 4 之呼称する).

得られた試料に対してX線回折装置(XRD-6100：島 津製作所製), 光学顕微鏡(BX-51P : OLYMPUS 製), SEM-EDS(JSM-6500F：日本電子製)および TEM-EDS (H-800B : HITACHI 製)による組織構造解析を行った. 維密化した鋳造材および押出材の機械的性質に関して は，各試料より引張試験片(平行部長さ：15mm)を採取 し，ひずみ速度 $5 \times 10^{-4} / \mathrm{sec}$ で引張試験(AUTOGRAPH AG-X : 島津製作所製)およよ゙，微小部硬度計(HMV-2T : 島津製作所製)を用いて硬度測定を行った.

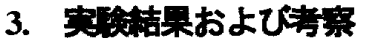

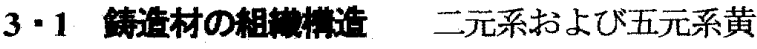
銅合金鋳造材(Cast 1 -4)の光学顕微鏡観察写真と画像解 析により得られた $\alpha, \beta$ 相の面積比率 $(\alpha / \beta)$ を図 1 に 示す. 全ての試料において $\alpha, \beta$ 相が明暸に観察され るとともに, Cast $2-4$ では数 $\mu \mathrm{m} \sim 50 \mu \mathrm{m}$ 程度の金属間 化合物(Intermetallic Compounds, IMC)が存在する. Cast1 は $\alpha$ 相が主なマトリックス構成相であるのに対して，
Cast2 4 では $\beta$ 相が主な構成相である. 表 1 に示したよ うに本研究で使用する鋳造材は Zn 添加量を 40mass\% に設定しており， $\mathrm{Cr}, \mathrm{Fe}, \mathrm{Sn}$ の添加により $\mathrm{Cu}$ に対す る Zn の割合が相対的に増加寸る. そのため, Cast2 4 では生成する $\beta$ 相の量が Cast1 と比較して多くなる. $\mathrm{Cr}$ と Fe の添加量が異なる Cast2 -4 において $\alpha$ 相， $\beta$ 相 および IMC において形状の違いは見られないが， Cr と Feの添加量が最も小さいCast4 では粗大な IMC の存 在量が他材料と比較して少ない. 図 2 に各鋳造材のX 線回折結果を示す. Cast1 では $\alpha$ 相のピーク強度が高い のに対して, Cast2 4 では $\beta$ 相のピーク強度が高く, 各 試料の $\alpha, \beta$ 相の存在量比は光学顕微鏡による組織観 察結果と相関を持つ. 他方, 同図の XRD 結果より Cast2 4の 44.5\%付近にCast1 では検出されないピークが 確認できる．同定の結果，1.36Cr0.52Fe のピーク $\left(44.548^{\circ}\right)$ であると考えられる. また Cast 3,4 の $44.5^{\circ}$ 付 近のピークは Cast2 のピークと比べて約 0.1 低角側に シフトしている.

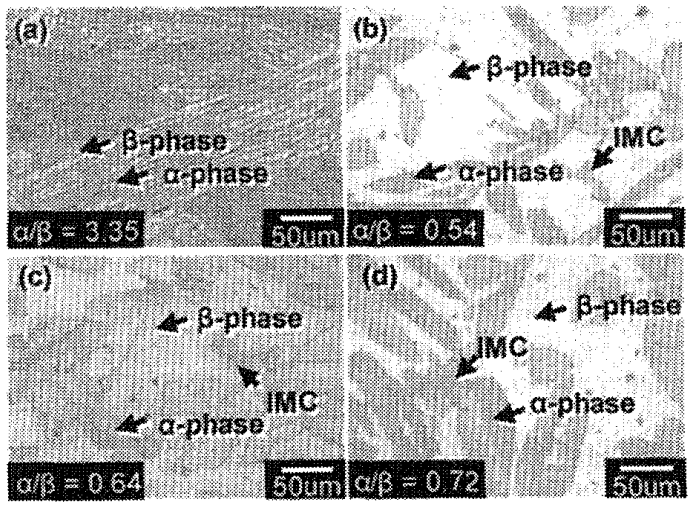

Fig. 1 Optical microstructures and area ratio of $\alpha-\beta$ phase $(\alpha / \beta)$ of cast ingots ; Cast1 (a), Cast2 (b), Cast3 (c) and Cast4 (d)

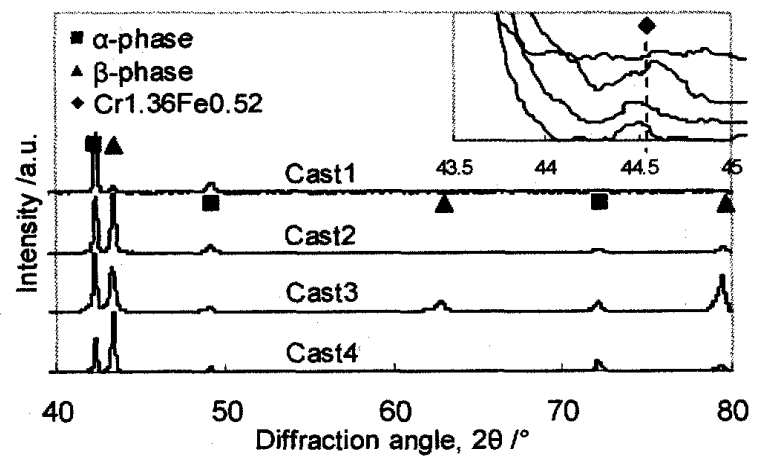

Fig. 2 X-ray diffraction patterns of cast $\mathrm{Cu}-40$ mass $\% \mathrm{Zn}$ brass alloy without additions (Castl) and with various contents of $\mathrm{Cr}$, Fe and Sn (Cast2 4). 
次に, SEM-EDSによる各相の点分析 $(\mathrm{N}=12)$ を行っ た結果の平均值を表 2 に示寸. Cast2 4 において $\alpha, \beta$ 相共に Cr, Fe, Snが検出されており，いずれの元素も マトリックスに固溶していると考えられる. Snにおい ては， $\alpha$ 相と比較して $\beta$ 相への固溶量が増加しており， $\alpha$ 相: $0.2 \mathrm{mass} \%, \beta$ 相: 0.9 mass\%であった. 他方, Castl においても， $\alpha ， \beta$ 相からわずかであるが， $\mathrm{Cr}, \mathrm{Fe}$, Sn が 0.06mass\%程度検出されており, SEM-EDS にお いて 0.1 1.0mass\%の微量元素を分析する場合, 誤差が 含まれる事に留意しなければならない. 他方, $50 \mu \mathrm{m}$ 程度の粗大な IMC は, Cast2 において Cr1.36Fe0.52 の 組成に近い分析結果であり，XRD 結果で得られた $44.5^{\circ}$ 付近のピークは Cr-Fe IMC に相当するといえる. 一方で, Cast3 と Cast 4 では, Cast2 と比較して Feに対 する Cr の比率が $10 \mathrm{mass} \%$ 程度高く, 前述した XRD 結 果でのピークシフトが生じた原因と考えられる.

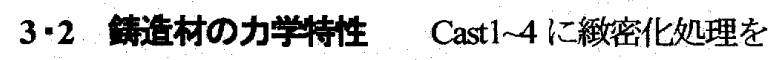
施した試料 H.T. cast $140 \alpha$ 相, $\beta$ 相の面積比率および 硬度(15 点測定の平均值) と, 以下の式(1)に示寸複合則 から得られるマトリックスの平均硬度を図 3 に示す。

$\mathrm{A}(\alpha) \times \mathrm{H}(\alpha)+\mathrm{A}(\beta) \times \mathrm{H}(\beta)=$ Matrix hardness

$A(\alpha, \beta)$ : Area ratio of $\alpha, \beta$-phase (\%)

$H(\alpha, \beta)$ : Vickers micro hardness of $\alpha, \beta$-phase $/ \mathrm{Hv} 0.025$

$\mathrm{Cr}, \mathrm{Fe}$ の添加量に関倸なく H.T. cast $2 \sim 4 の \alpha, \quad \beta$ 相 の硬度は, H.T. cast1 と比較して 12\%, 19\%増加した. またEDS 分析より緻密化处理前のCast2 4 とほぼ同様, $\alpha$ 相中に 0.09 mass $\% \mathrm{Cr}, 0.21 \mathrm{mass} \% \mathrm{Fe}, \quad 0.18 \mathrm{mass} \% \mathrm{Sn}$, $\beta$ 相中に 0.07 mass $\% \mathrm{Cr}, 0.15 \mathrm{mass} \% \mathrm{Fe}, 0.77$ mass $\% \mathrm{Sn}$ が 険出されており， $\alpha$ 相と $\beta$ 相の硬度増加の要因として, $\mathrm{Cr}, \mathrm{Fe}, \mathrm{Sn}$ による固溶強化が考えられる. さらに, H.T. castl と比較して, $\beta$ 相の比率が高い材料であるため,

Table 2 EDS point analysis results on $\alpha$-phase, $\beta$-phase and coarse $\mathrm{IMC}$ in cast $\mathrm{Cu}-40$ mass $\% \mathrm{Zn}$ brass alloys (Cast $1 \sim 4$ ).

\begin{tabular}{ccccccc}
\hline \multirow{2}{*}{ Materials } & Phase & \multicolumn{5}{c}{ Elements (mass\%) } \\
\cline { 3 - 7 } & & $\mathrm{Cu}$ & $\mathrm{Zn}$ & $\mathrm{Cr}$ & $\mathrm{Fe}$ & $\mathrm{Sn}$ \\
\hline \multirow{2}{*}{ Cast1 } & $\alpha$ & 63.95 & 35.87 & 0.06 & 0.07 & 0.06 \\
& $\beta$ & 56.39 & 43.40 & 0.04 & 0.08 & 0.10 \\
\hline \multirow{4}{*}{ Cast2 } & $\alpha$ & 63.47 & 35.99 & 0.10 & 0.21 & 0.23 \\
& $\beta$ & 56.30 & 42.48 & 0.09 & 0.17 & 0.96 \\
& $\mathrm{IMC}$ & 2.84 & 2.27 & 64.53 & 30.20 & 0.16 \\
\hline \multirow{4}{*}{ Cast3 } & $\alpha$ & 66.37 & 33.07 & 0.07 & 0.28 & 0.21 \\
& $\beta$ & 59.77 & 39.05 & 0.05 & 0.17 & 0.96 \\
& $\mathrm{IMC}$ & 1.64 & 1.04 & 77.46 & 19.66 & 0.19 \\
\hline \multirow{3}{*}{ Cast4 } & $\alpha$ & 63.81 & 35.74 & 0.10 & 0.23 & 0.13 \\
& $\beta$ & 56.52 & 42.53 & 0.06 & 0.13 & 0.76 \\
& $\mathrm{IMC}$ & 3.22 & 2.44 & 77.33 & 16.91 & 0.10 \\
\hline \multirow{6}{*}{} & & & & & &
\end{tabular}

式(1)の複合則より求められるマトリックス硬度は $29 \%$ 高くなった. 他方, $50 \mu \mathrm{m}$ 程度の粗大な $\mathrm{Cr}-\mathrm{Fe}$ IMC $の$ 硬さは，すべての試料で約 $400 \mathrm{Hv}$ となり，マトリック スと比較して硬質な相である. 次に, H.T. cast1 4 材の 引張試験結果を図 4 に示す. H.T. cast2 4 の耐力值, 最 大応力值は共に, H.T. cast1 と比較して増加傾向を示し, H.T. cast2 4 耐力值はH.T. cast1 (99MPa) と比較して約 90\%向上した. 伸び值は H.T. cast2-4 でばらつきがあり， $\mathrm{Cr}$ と $\mathrm{Fe}$ の添加量が最も多いHT. cast 2 で平均 $13 \%$ であ った. 一方, Cr, Fe の添加量が最も少ない H.T. cast 4 では伸び值 44\%を示した. H.T. cast2 -4 において, 引張 試験片の破断面を SEM-EDS を用いて分析すると, 破 断面の一部に数十 $\mu \mathrm{m}$ 程度の脆性破面が観察され, $\mathrm{Cr}$ と $\mathrm{Fe}$ の濃化が見られた. 脆性破面は図1で示した粗大 な $\mathrm{Cr}$-Fe IMC の破壊面であり， $\mathrm{Cr}$ と $\mathrm{Fe}$ 添加量が多い H.T. cast2では脆性破面が多く観察され，延性を低下さ せた要因であると考えられる.これに対して, H.T. cast4 の破断面においては，脆性破面は少なく，粗大な $\mathrm{Cr}-\mathrm{Fe}$ IMC が少ないことから，延性の低下が抑制されたと考 えられる. 他方, 耐力值の増加に関しては, 前述のマ トリックス硬度と相関が見られることから(1) $\beta$ 相比率 の増加, (2) Cr, Fe, Sn 添加元素による固溶強化と考元 られる。

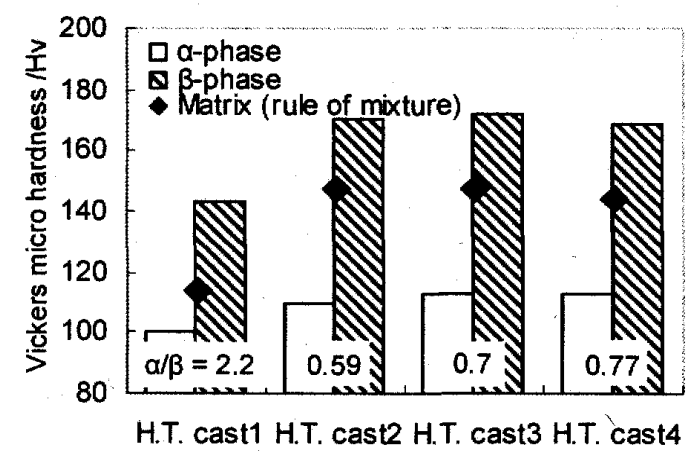

Fig. 3 Vickers micro hardness of $\alpha$-phase, $\beta$-phase and $\alpha+\beta$ matrix in compacted cast materials (H.T. cast $1-4$ ).

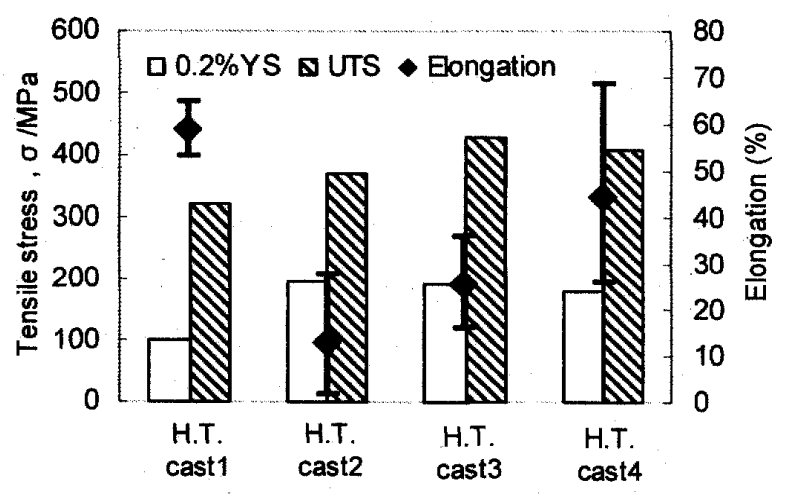

Fig.4 Tensile properties of compacted cast materials (H.T. cast $1-4)$. 

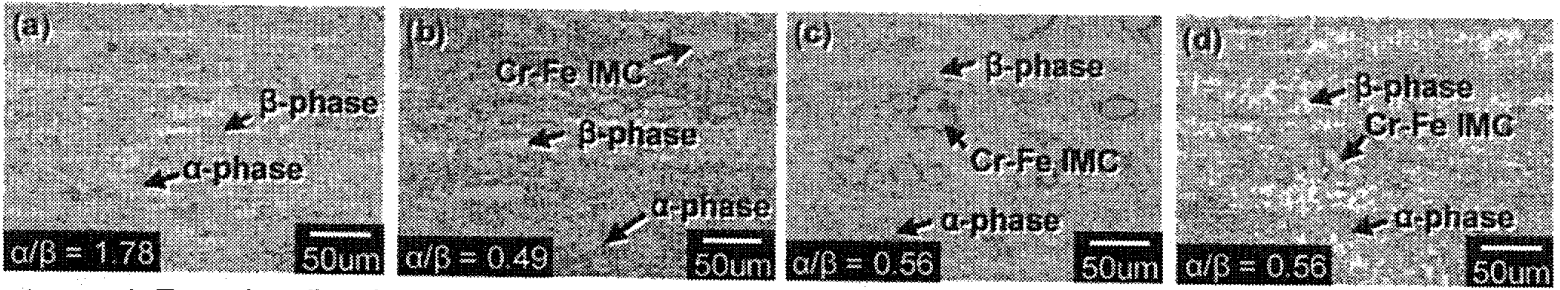

$\rightarrow$ Extrusion direction

Fig.5 Optical microstructures and area ratio of $\alpha-\beta$ phase $(\alpha / \beta)$ of extruded material ; Ext1 (a), Ext2 (b), Ext3 (c) and Ext4 (d)

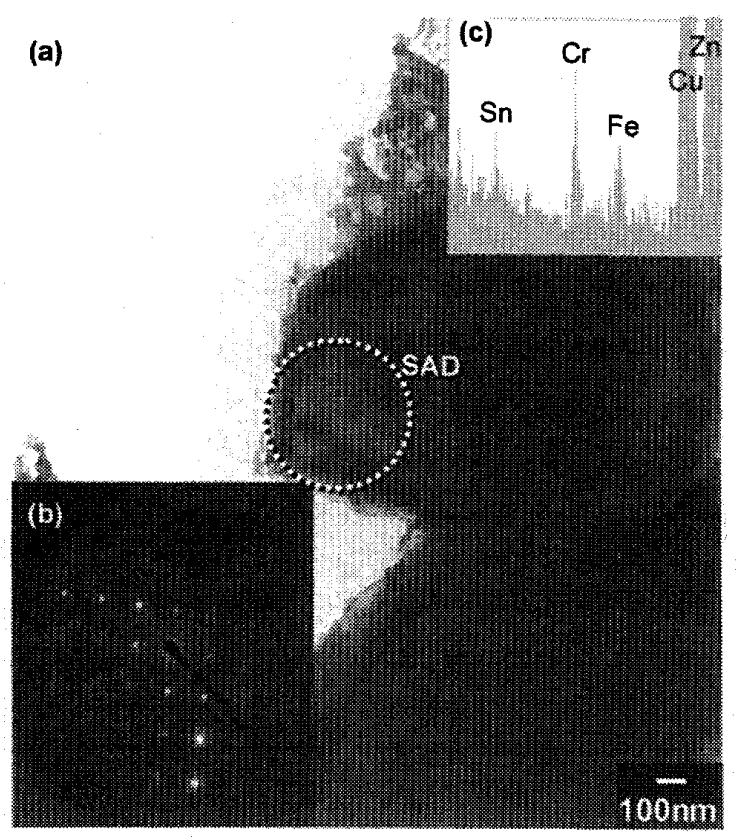

Fig.6 TEM image (a), selected area diffraction pattern (b) and TEM-EDS results (c) on transversal cross-section of extrusion direction of $\alpha$-phase in Ext2 material.

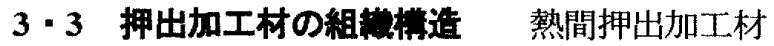
Extl 4 の断面組織観察結果と $\alpha, \beta$ 相の面積比率 $(\alpha)$ $\beta$ )を図 5 に示す. Ext1 では押出加工により， $\alpha$ 相と $\beta$ 相は押出方向に延役した形状である.一方，Ext2 4 で は $\beta$ 相のみ押出方向に延伸しており， $\alpha$ 相は粒状であ る.これは, 熱間押出加工における予加熱 $923 \mathrm{~K}, 180 \mathrm{sec}$ 保持により，二元系黄銅合金では $\alpha-\beta$ 二相組織である の対して，五元系黄銅合金は $\beta$ 相単体に相変態したこ とで，押出加工後の泠却により $\beta$ 相から数 $\mu \mathrm{m}$ 程度の

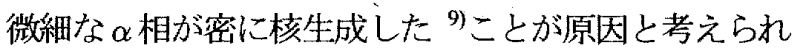
る. 他方, Cr-Fe IMC は押出方向に沿って連続して存在 しており，粗大な化合物は押出加工により破壊・分断 されたと考えられる.また，押出材のSEM-EDS とXRD による組織構造解析の結果, $\alpha$ 相と $\beta$ 相における $\mathrm{Cr}$, $\mathrm{Fe}, \mathrm{Sn}$ 添加元素の固溶量および Cr-Fe IMC 組成に押出 加工前後での変化は見られなかった. 次に, 試料 Ext2 について TEM-EDS による内部組織解析結果を図 6，7 に示寸．試料は押出方向に垂直に切断した面であり， 数 $\mu \mathrm{m}$ の粒状相と，網目状に腐食された相の二相が観

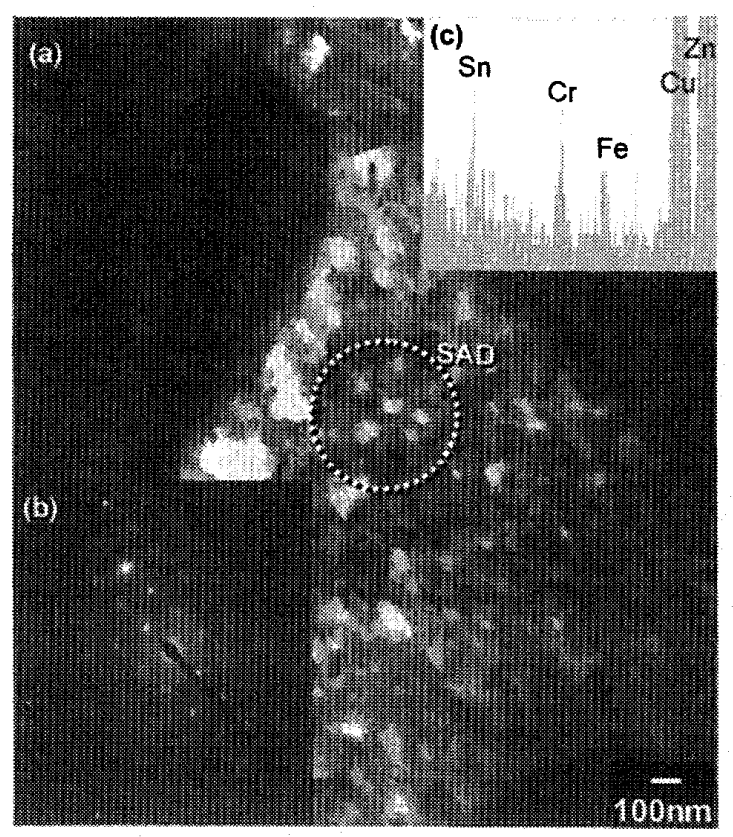

Fig.7 TEM image (a), selected area diffraction pattern (b) and TEM-EDS results (c) on transversal cross-section of extrusion direction of $\beta$-phase in Ext2 material.

察された．図6(a)に示した粒状相の回折パターン(b)を 解析した結果, 格子定数 $\mathrm{a}=3.756 \AA$, 電子線入射方向 [001] $0 \mathrm{fcc}$ 構造の $\alpha$ 相であると考えられる. また図 7(a) に示した網目状相の回折パターン(b)から，格子定数 a $=2.930 \AA$, 電子線入射方向 $[-111]$ o bcc 構造の $\beta$ 相であ ると考えられる.また $\beta$ 相の回折パターンには回折ス ポットを結ぶ線状のストリークが観察された.これら は電子線入射方向に垂直, つまり[2-1-1]方向の多数の 積層欠陥もしくは双晶の存在を示しており $\left.{ }^{10}, 11\right)$ ，熱間 押出加工により導入されたひずみによるものと考えら れる.一方， $\alpha$ 相には $\beta$ 相で見られるストリークは確 認できず，前述したように $\alpha$ 相は熱間押出加工後に核 生成することから，押出加工過程で導入される積層欠 陥もしくは双晶は， $\alpha$ 相内部には少ないと考えられる. 他方, 図 6，7 (c)に示したそれぞれの相に関する TEM-EDS $の$ 分析結果より, 鋳造材と同様に $\alpha$ 相と $\beta$ 相 共に $\mathrm{Cr}, \mathrm{Fe}, \mathrm{Sn}$ の元素が検出された. 
$3: 4$ 押出加工材の力学特性 熱間押出加工材に おいて微小部硬度の測定を行った。図 5 に示した組織 写真より押出加工材の組織は微細であり， $\alpha$ 相と $\beta$ 相 を区別して硬度測定を行うことが困難なため，エッチ ングを施さずに鏡面仕上げの状態で，金属間化合物を 避けてマトリックスの硬度を測定した。二元系黄銅合 金押出材 Extl のマトリックス平均硬度は $131( \pm 11) \mathrm{Hv}$ と求められ，鋳造材 Cast1 の值(114Hv) と比較して約 $15 \%$ 向上した. この要因として， $\beta$ 相比率の増加と押 出加工時のひずみの導入が挙げられる. 一方, 五元系 黄銅合金押出材 Ext2 4 に関しては，添加元素量の大小 に関わらず，平均 154 158Hv の硬さを保持する，それ ぞれの鋳造材硬さと比較すると, 約 6\%の向上となった。 五元系黄銅合金押出材と鋳造材 $\alpha / \beta$ 值は共に 0.5 前 後と同程度であることから，押出材の硬度増加の主要 因として, 押出加工によるひずみの導入が考えられる. 次に, Ext1 4の引張試験結果老図8 亿示寸. Ext2 4 で は平均して耐力值が $300 \mathrm{MPa}$, 最大引張応力が $599 \mathrm{MPa}$ となり，図 4 に示した鋳造材(H.T. cast2 4)の引張試験 結果と比較して, 耐力, 最大引張強さはそれぞれ $58 \%$, 49\%向上した．また，鋳造材に比べて伸びのばらつき が改善され，全ての試験片で伸び值 30\%以上を保持し た.これは，図 5 に示した押出材組織において， $\alpha$ 相， $\beta$ 相および Cr-Fe IMC が押出加工により均一な微細組 織に変化したためと考えられる. 他方, Ext1(YS： 244MPa，UTS : 467MPa) と比較して Ext2 4 は平均して 耐力の平均值が $23 \%$ 増加, 最大応力は $28 \%$ 増加した. 耐力值の増加に関しては鋳造材と同様の強化機構が考 えられる。

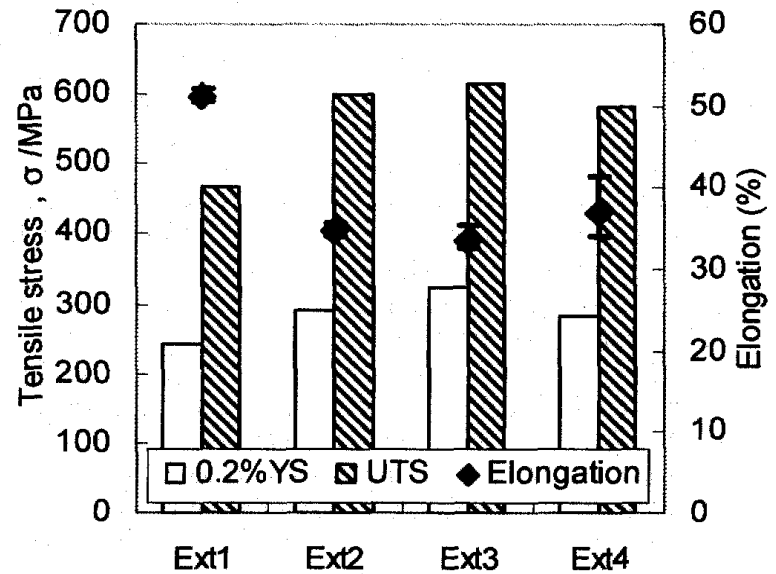

Fig.8 Tensile properties of extruded cast $\mathrm{Cu}-40$ mass $\% \mathrm{Zn}$ brass alloy without additions (Ext1) and with various contents of $\mathrm{Cr}$, Fe and Sn (Ext2-4).
3-5 高強度化因子の寄与率 前節の結果より， 五元系黄銅合金は二元系黄銅合金と比較して高強度特 性を有しており，組織構造解析の結果，その高強度化 の要因として, (1) $\alpha$ 相と $\beta$ 相の面積比率 $(\alpha / \beta)$ の変化, (2) $\mathrm{Cr}, \mathrm{Fe}, \mathrm{Sn}$ の微量固溶の二点が考えられる. そこで, 上述の強化機構に関して，押出材に対して熱処理を施 し，ひずみを除去した後， $\alpha$ 相と $\beta$ 相の面積比率を変 化させた試料 H.T.ext1〜4 を調查した. H.T.ext1 4 にお ける $\alpha$ 相と $\beta$ 相の硬度測定結果を表 3 に示寸.ここで, $800^{\circ} \mathrm{C}$ に打いて水焼入れを行った試料のマトリックス は $\beta$ 相単相であるため， $\beta$ 相のみの硬度を示す．H.T. extl の硬度の平均值は $\alpha$ 相 : $98( \pm 4) \mathrm{Hv}, \beta$ 相 : $149( \pm$ 6) Hv であり，他方, H.T. ext2 4 は平均で $\alpha$ 相 : 108 (士 1) $\mathrm{Hv}, \quad \beta$ 相 : $170( \pm 1) \mathrm{Hv}$ と求められ, 熱処理温度の 違いによる硬度のばらつきは小さい．また H.T. ext2 4 の $\alpha$ 相と $\beta$ 相に対して, SEM-EDSによる点分析を行っ た結果, 微量の $\mathrm{Cr}, \mathrm{Fe}, \mathrm{Sn}$ の固溶元素が検出された. それぞれの熱処理材において固溶元素は平均して $\mathrm{Cr}$, Feがそれぞれ 0.12mass\%，0.25mass\%，また Snに関し ては $\alpha$ 相中に $0.24 \mathrm{mass} \%, \beta$ 相中に $0.85 \mathrm{mass} \%$ 検出され たことから，熱処理材 H.T.ext2 4 における $\alpha$ 相と $\beta$ 相 は，微量の $\mathrm{Cr}, \mathrm{Fe}, \mathrm{Sn}$ 元素によって, 鋳造材およひ押 出材と同様に固溶強化がなされていると考えられる. よって，同熱処理材におうける $\alpha$ 相と $\beta$ 相の面積比率の 变化と耐力值の関係を調查し，上述した五元系黄銅合 金における二つの高強度化因子の寄与率を求めた．熱 処理材の $\alpha-\beta$ 相マトリックス面積比率 $(\alpha / \beta)$ と耐力值 の関係を図 9 に示す。二元系，五元系熱处理材におい $\tau$, マトリックス中の $\beta$ 相面積比率の増加 $(\alpha / \beta$ 值の減 少)に伴い耐力值が増加することが分かる．二元系，五 元系黄銅合金の $\alpha / \beta$ 值による耐力値の変化は

$$
\begin{array}{lll}
\mathrm{YS}_{\mathrm{Cu}_{1}-02 \mathrm{Zn}}=-73(\alpha / \beta)+235 & (\mathrm{MPa}) \\
\mathrm{YS}_{\mathrm{Cu}_{\mathrm{n}-10 \mathrm{Zn}-\mathrm{CrFSn}}}=-88(\alpha / \beta)+265 & (\mathrm{MPa})
\end{array}
$$

として記述できる. 上記 2 式の差が $\alpha, \beta$ 相に固溶し た微量の $\mathrm{Cr}, \mathrm{Fe}, \mathrm{Sn}$ 元素による固溶強化であると考え られる，よって，黄銅合金に微量の $\mathrm{Cr}, \mathrm{Fe}, \mathrm{Sn}$ 元素を 添加することによって得られる固溶強化幅 $\Delta Y S$ は以 下の式として求められる.

$$
\Delta \mathrm{YS}=\mathrm{YS}_{\mathrm{Cu}-10 \mathrm{Zn} \mathrm{H} \text {-CFeSn }}-\mathrm{YS}_{\mathrm{Cu}-40 \mathrm{Zn}}=30-15(\alpha / \beta)
$$

固溶による耐力值の増加幅は $\alpha / \beta$ 值の増加，つまり， $\alpha$ 相面積率の増加に伴い減少することが分かる。これ は表 3 の硬度測定結果からも分かるように， $\alpha$ 相と比 較して， $\beta$ 相において， $\mathrm{Cr}, \mathrm{Fe}, \mathrm{Sn}$ の微量固溶元素に よる硬化率が高いことに起因すると考えられる. 
Table 3 Vickers micro hardness of $\alpha$-phase and $\beta$-phase in the heat-treated materials (H.T. extl $\sim$ ) $/ \mathrm{Hv}$

\begin{tabular}{|c|c|c|c|c|c|c|c|c|c|}
\hline & & $800^{\circ} \mathrm{CW} . \mathrm{Q}$ & $800^{\circ} \mathrm{CAN}$ & $\begin{array}{l}800^{\circ} \mathrm{CAN}+ \\
750^{\circ} \mathrm{CW} . \mathrm{Q} .\end{array}$ & $\begin{array}{l}800^{\circ} \mathrm{CAN}+ \\
700^{\circ} \mathrm{CW} . \mathrm{Q} .\end{array}$ & $\begin{array}{l}800^{\circ} \mathrm{CAN}+ \\
650^{\circ} \mathrm{CW} . \mathrm{Q}\end{array}$ & $\begin{array}{l}800^{\circ} \mathrm{CAN} \\
600^{\circ} \mathrm{CW} . \mathrm{Q}\end{array}$ & $\begin{array}{l}800^{\circ} \mathrm{CAN}+ \\
550^{\circ} \mathrm{CW} . \mathrm{Q}\end{array}$ & $\begin{array}{l}800^{\circ} \mathrm{CAN}+ \\
500^{\circ} \mathrm{CW}, \mathrm{Q}\end{array}$ \\
\hline H.T. & $\alpha$ & - & 93 & 98 & 102 & 91 & 98 & 103 & 99 \\
\hline ext1 & $\beta$ & 159 & 145 & 146 & 152 & 142 & 145 & 153 & 152 \\
\hline H.T. & $\alpha$ & - & 107 & & & & & & 111 \\
\hline ext2 & $\beta$ & 171 & 169 & & & & & & 170 \\
\hline $\mathrm{HT}$ & $\alpha$ & - & 107 & & & & & & 107 \\
\hline ext3 & $\beta$ & 172 & 171 & & & & & & 168 \\
\hline H.T & $\alpha$ & - & 109 & & & & & & 108 \\
\hline ext4 & $\beta$ & 171 & 167 & & & & & & 167 \\
\hline
\end{tabular}

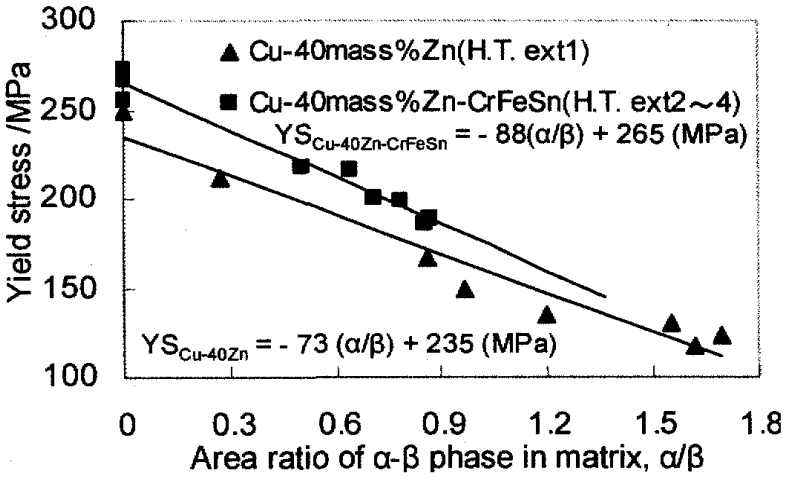

Fig. 9 Relationship between $\alpha / \beta$ area ratio and yield stress of $\mathrm{Cu}-40 \mathrm{Zn}$ and $\mathrm{Cu}-40 \mathrm{Zn}-\mathrm{CrFeSn}$ (H.T. ext1 4).

\section{4. 結 语}

$\mathrm{Cr}, \mathrm{Fe}, \mathrm{Sn}$ 元素を微量添加した $\alpha-\beta$ 二相黄銅合金の 組織構造解析, および力学特性を調查し, 微量添加元 素による黄銅合金の強化機構について検討した結果, 以下の知見を得た.

(1) 五元系黄銅合金鋳造材は， $\beta$ 相を主とした $\alpha-\beta$ 二 相マトリックスと Cr-Fe IMC から構成された。また $\alpha$ 相と $\beta$ 相には Cr, Fe, Sn の微量固溶元素が存在し, そ れぞれ固溶することにより硬度は $12 \%, 19 \%$ 増加した。 また引張試験において耐力值 $190 \mathrm{MPa}$ を示すが, 晶出 した数十 $\mu \mathrm{m}$ 程度の粗大な $\mathrm{Cr}-\mathrm{Fe} \mathrm{IMC} に よ り$ 伸ひ值は 13〜70\%とばらつきを有した.

(2) 五元系黄銅合金鋳造材の押出加工材は耐力值 $300 \mathrm{MPa}$, 最大応力值 $599 \mathrm{MPa}$ ，伸び值 $30 \%$ 以上を保持 し, 高強度・高延性を示した。粗大な $\mathrm{Cr}$ - Fe IMC は押 出加工で生じる塑性流動により押出方向に配向し, ま た破壊・分断して微細に分散することで，鋳造材と比 較して伸びのばらつきが减少した。

(3) 組織構造解析, 力学特性の調查によって, 五元系黄 銅合金の強化機構として(1) $\alpha / \beta$ 值の変化，(2) Cr, Fe, Sn の微量固溶の二点が考えられる. 五元系黄銅合金の $\alpha$ 相と $\beta$ 相の面積比率の変化による耐力值の増加幅は,

$$
\mathrm{YS}_{\mathrm{Cu}-40 \mathrm{Zn}-\mathrm{CrFSn}}=-88(\alpha / \beta)+265 \quad(\mathrm{MPa})
$$

と求められた. また $\mathrm{Cr}, \mathrm{Fe}, \mathrm{Sn}$ 元素添加による固溶強 化幅 $\triangle Y S$ は

$$
\Delta \mathrm{YS}=\mathrm{YS}_{\mathrm{Cu}-40 \mathrm{Zn}-\mathrm{CrFeSn}}-\mathrm{YS}_{\mathrm{Cu}-40 \mathrm{Zn}}=30-15(\alpha / \beta)
$$

と記述できることを明らかとした。

\section{甜 辞}

本研究にお於る，供試材の作製には日本アトマイズ 加工株式会社に協力を仰いだ. TEM 観察に関しては, 大阪大学超高圧電子顕微鏡センターの協力によるもの である．関係各位に対しここに謝意を表する。

\section{文献}

(1) H. Mindivan, H. Çimenoglu, E.S. Kayali, Microstructures and wear properties of brass synchroniser rings, Wear 254 (2003), pp.532-537.

(2) S.M. Sayed, E.A. Ashour, G.I. Youssef, Effect of sulfide ions on the corrosion behaviour of $\mathrm{Al}$ brass and $\mathrm{Cu}_{10} \mathrm{Ni}$ alloys in salt water, Materials Chemistry and Physics 78 (2003), pp.825-834.

(3) G. Mauvoisin, O. Bartier, R. El Abdi, A. Nayebi, Influence of material properties on the drilling thrust to hardness ratio, International Joumal of Machine Tools \& Manfacture 43 (2003), pp.825-832.

(4) C. Vilarinho, J.P. Davimb, D. Soares, F. Castro, J. Barbosa, Influence of the chemical composition on the machinability of brasses, Joumal of Materials Processing Technology 170 (2005), pp.441-447.

(5) X. Wang, J. Zhao, J. He, Investigation on the microstructure and mechanical properties of the spray -formed $\mathrm{Cu}-\mathrm{Cr}$ alloys, Materials Science and Engineering A 460-461 (2007), pp.69-76.

(6) K. Kobayashi, R. Ozaki, T. Etoh, Effect of dispersive precipitation particles on work hardening of $\mathrm{Cu}-\mathrm{Fe}$ alloy, Jowanal of Japan Research Institute for Advanced Copper-Base Materials and Technologies, 36 (1997), pp.175-181.

(7) D. Lu, J. Wang, W. Zeng, Y. Liu, L. Lu, B. Sun, Study on high-strength and high-conductivity $\mathrm{Cu}-\mathrm{Fe}-\mathrm{P}$ alloys", Materials Science and Engineering A 421 (2006), pp.254-259

(8) C.Vilarinho, D. Soares, F. Castro, Contribution to the knowledge of the $\mathrm{Cu}-\mathrm{Sn}-\mathrm{Zn}$ system for compositions close to brass alloys, Journal of Alloys and Compounds 379 (2004), pp.61-165.

(9) C. Mapelli, R. Venturini, Dependence of the mechanical properties of an $\alpha / \beta$ brass on the microstructural features induced by hot extrusion, Scripta Materialia 54 (2006), pp.1169-1173.

(10) M. Han, M. Han, J.C. Bennett, M.A. Gharghouri, J. Chen, C.V. Hyatt, Understanding modulated twin transition at the atomic level, Acta Materialia 55 (2007), pp.1731-1740.

(11) J. W. SEO, D. Schryvers, TEM investigation of the microstructure and defects of $\mathrm{CuZr}$ martensite. PART I: morphology and twin systems, Acta Materialia Vol. 46, No. 4 (1998), pp.1165-1175. 